\title{
Antibiotic use and practices in commercial poultry laying hens in Ogun State Nigeria
}

\author{
Oluwawemimo O. Adebowale ${ }^{1 *}$ Olanike K. Adeyemo ${ }^{2}$ \\ Olajoju Awoyomi ${ }^{1}$ Racheal Dada ${ }^{1}$ Oluseyi Adebowale ${ }^{3}$
}

\section{Keywords}

Poultry, layer chicken, resistance to antibiotics, antibiotic residues, farm manager, Nigeria

Accepted: 16 February 2016

Published: 4 July 2016

\begin{abstract}
Summary
Poultry production contributes largely to the Nigerian economy. However, antibiotics misuse by poultry farmers has resulted in multidrug resistance and impeded efficiency of antibiotic treatments in the industry. The study was carried out to assess antibiotic usage in commercial poultry farms. A survey using a structured farm-manager questionnaire was conducted to obtain information on socioeconomic characteristics of the farm owners or managers, the types of antibiotics used, their frequency and purpose of use, the awareness of antibiotics usage and associated consequences, and farmers' preferred channels of information on prudent antibiotic usage. The respondents' level of education was university or equivalent $(70.9 \%)$, high school $(12.6 \%)$, or no formal education $(13.6 \%)$. Antibiotics were primarily used for prophylaxis $(>60 \%)$ and therapeutics $(<15 \%)$. Gentamicin $(76.7 \%)$ was the most used, followed by tetracycline $(64.1 \%)$, enrofloxacin and ciprofloxacin $(57.3 \%)$, furazolidone $(49.5 \%)$, streptomycin $(46.6 \%)$, furaltadone $(43.7 \%)$, chloramphenicol $(41.7 \%)$, penicillin $(25.2 \%)$, erythromycin $(24.3 \%)$, and nalidixic acid $(11.7 \%)$. About half of the farms used banned furazolidone and chloramphenicol. In total 82 (79.6\%) farmers were aware that the use of random antibiotics in the treatment of improperly diagnosed diseases can lead to antibiotic resistance. However 73 (70.9\%) were less aware that antibiotics misuse in animals poses a serious threat to human health. Antibiotics were not prudently used by poultry producers, whose lack of awareness may contribute to the issue. It is anticipated that the results of this survey will assist in developing relevant policies toward controlling antibiotic use in poultry farms in Nigeria.
\end{abstract}

- How to cite this article: Adebowale O.O., Adeyemo O.K., Awoyomi O., Dada R., Adebowale O., 2016. Antibiotic use and practices in commercial poultry laying hens in Ogun State Nigeria. Rev. Elev. Med. Vet. Pays Trop., 69 (1): 41-45

\section{INTRODUCTION}

Livestock contributes $40 \%$ of the global value of agricultural output and supports the livelihoods and food security of almost a billion people worldwide (Carrique-Mas et al., 2015). Rapidly rising incomes

1. Department of Veterinary Public Health and Reproduction, College of Veterinary Medicine, Federal University of Agriculture, Abeokuta, Nigeria.

2. Department of Veterinary Public Health and Preventive Medicine, University of Ibadan, Nigeria.

3. Department of Agricultural Extension and Rural Development, University of Ibadan, Nigeria.

* Corresponding author

Tel.: +234 (0)9085608043

Email: oluwawemimo1@yahoo.com

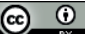

https://creativecommons.org/licenses/by/4.0/ and urbanization, combined with underlying population growth are driving the demand for meat and other animal products in many developing countries (Carrique-Mas et al., 2015). In Nigeria, the poultry industry has contributed to the economic growth and assumed greater importance in improving employment opportunity and animal food production (Adebayo and Adeola, 2005).

Antibiotics play a significant role in controlling infectious diseases. The past few decades, however, have witnessed a steady increase in the number and diversity of antibiotic-resistant bacteria, rendering some bacterial infections virtually untreatable (Hurd et al., 2004). The cost of resistance associated with the treatment of infections caused by antibiotic-resistant bacteria has increased manyfold (Ghosh and Lapara, 2007). The pervasive use of antibiotics for both therapeutic and non-therapeutic purposes is associated with the occurrence of antibiotic-resistant bacteria, due to selective pressure in favor of resistant bacteria (Ghosh and Lapara, 2007). 
Bacterial diseases are recognized as an important risk factor in poultry health management. Every poultry farmer is aware of the risk of bacterial infections and their subsequent effect on mortalities, productivity, and profitability. Consequently, farmers in the tropics spend more money on control and management of bacterial diseases than on any other form of poultry diseases. A recent survey in Nigeria estimated that layer farmers spend over 35\% of their cost of medication on treating bacterial diseases up to the end of lay (Adejoro, 2007). Antibiotic resistance translates into costs of about 75 million US\$ to medicate 40 million commercial layers in Nigeria to end of lay. Accordingly, this has led farmers to the inappropriate use and handling of antibiotics. The persistent use of antibiotics is suspected to be the major cause of antibiotic resistance in man and animal (Adejoro, 2007). The overall relationship between drug use and resistance is well established and based on laboratory, cross-sectional, case-control and prospective studies (Olonitola et al., 2015). Also, self-medication with antibiotics, use of human antibiotics in food animals and non-regulated prescriptions are increasingly alarming and may have contributed to antibiotic resistance scourge in the poultry industry in Nigeria.

Furthermore, the rationale for prophylaxis stems from the fact that antibiotic is more efficient when used for prevention rather than for therapeutics (Gustafson and Bowen, 1997). However, misuse of antimicrobials may lead to carryover of residues in animal products, which may result in detrimental effects on consumers and public health in general (Anderson et al., 2003; Cheng et al., 2012; FAO, 2010). Measures to minimize and contain resistance are thus essential to ensure the continued availability and efficacy of veterinary and human antimicrobial drugs. Containment of antibiotic resistance depends on the responsible use of antibiotics, which prompted us to investigate the commonly used antibiotics and farmers' awareness and practices to antibiotic usage.

\section{MATERIALS AND METHODS}

\section{Study location}

This study was conducted from March to July 2011 in Ogun State, Nigeria, which holds the largest concentration of commercial laying poultry in the country. This State is located in the southeast of Nigeria, at $3^{\circ} 19^{\prime} 65^{\prime \prime} \mathrm{E}$ and $7^{\circ} 09^{\prime} 77^{\prime \prime} \mathrm{N}$, at an elevation of 51.5 meters, and a total land area of $16,762 \mathrm{~km}^{2}$. Ogun State, also known as the Gateway State, shares an international border with Benin in the west, and interstate boundaries with Oyo in the north, Lagos in the south and Ondo in the east.

\section{Study design and poultry farm selection}

The target population was commercial poultry farms with a population of 200 or more laying hens. Commercial laying-hen farms were selected for study, as they constitute over $89 \%$ of poultry production in the study area, whereas broiler farms account for only $2.2 \%$. In addition, laying hens are more lucrative and produce all year around A list of 200 poultry farms in Ogun State, from which 106 were initially randomly selected for this study, was obtained from the Ministry of Agriculture. In cases where farms were not reachable because of lack of addresses, distance or unwillingness to participate, they were conveniently replaced with other farms. Eventually, 103 farms participated in the survey. We only sampled 103 farms because of logistics and because most farms were located in rural communities with or without addresses, and locating them was difficult. One of the farmers refused to participate because of the lack of feedback and benefits from past studies in which he had been involved.

A farm manager questionnaire was designed and pretested on a small sample of 10 commercial laying-hen farms outside Ogun State to detect any flaws in the wording, sequencing of the questions and consistency. The internal validation of the questionnaire was done using Cronbach's alpha (test for reliability $=0.7$ ), which ranges from $r=0$ to 1 , where $r=0.7$ or greater is considered as sufficiently reliable (Nunnally and Bernstein, 1994). The questionnaire was not however re-pretested to ensure repeatability of respondents' responses.

The questionnaire consisted of a brief introduction, which explained the purpose of the questionnaire, the importance of the respondent's participation and a statement guaranteeing confidentially. The rest comprised questions to gather information on the i) socioeconomic characteristics of the farm owners/managers, ii) types of antibiotics commonly used, iii) frequency and purpose of use, iv) awareness of poultry farmers on the use of antibiotics and associated problems, and v) sources and appropriate channel of information on antibiotic usage. The questionnaire was administered to either farm owners or managers by two of the authors and filled in by the respondents. The majority of the respondents were well educated. On the other hand, the few farmers who were uneducated were assisted with filling in the questionnaire. All questions were closed-ended as respondents were given options to select.

\section{Data analysis}

Data were processed with Microsoft Excel 2007 and analyzed as descriptive statistics. All graphic presentations were performed with Graphpad prism 6.0. Prevalence and 95\% confidence intervals were determined using Graphpad Quickcalcs.

\section{RESULTS}

\section{Poultry characteristics}

Major strains of layers raised in the study area included Nera Brown, Black Haco, Lohmann brown and Issa brown. The flock size of the farms studied ranged from 500 to 50,000 birds.

\section{Farmers' socio-economic characteristics}

The results showed that among the respondents 74 (71.8\%) were men and $15(14.6 \%)$ were women. With regard to the level of education $73(70.9 \%)$ had attended the university or an equivalent establishment, 13 (12.6\%) had a high school level and 14 (13.6\%) no formal education.

\section{Antibiotics commonly used by laying-hen farmers}

The choice and commonly used antibiotics among farmers were investigated. All respondents recruited for the study had specified the use of antibiotics for their farm poultry production. Antibiotics used among farmers included a whole range of different classes. However, farmers' preference of antibiotics was, in the following, order gentamicin $79(76.7 \%)$, tetracycline $66(64.1 \%)$, enrofloxacin and ciprofloxacin $59(57.3 \%)$, furazolidone 51 (49.5\%), streptomycin 48 (46.6\%), furaltadone 45 (43.7\%), chloramphenicol 43 (41.7\%), penicillin $26(25.2 \%)$, erythromycin 25 (24.3\%), and nalidixic acid $12(11.7 \%)$ (Figure 1). Out of 103 farmers interviewed, 20.4\% used tetracyclines always, whereas nalidixic acid was never used by $85.4 \%$. Gentamicin was a common antibiotic occasionally used by 61 (59.2\%) farmers (Table I). The purpose of use of antibiotics was mainly prophylactic $(>60 \%)$ and less frequently therapeutic $(<15 \%)$ (Figure 2$)$.

\section{Antibiotic administration in poultry}

Seventy-five poultry farmers believed that veterinary prescriptions were not necessary because of long years of experience in the poultry business. However, 81 (78.6\%, 95\% CI, 69.7-85.5) agreed that 
antibiotics used in poultry should be regulated and used when prescribed by veterinarians only. When asked if antibiotics could be discontinued when clinical signs of infection subside, 53 (51.5\%, 95\% CI, 41.9-60.8) agreed this could be done. It was also observed that 67 $(65.0 \%, 95 \%$ CI, 55.4-73.5) agreed it was always advisable to administer antibiotics regularly to prevent diseases outbreak on the farm.

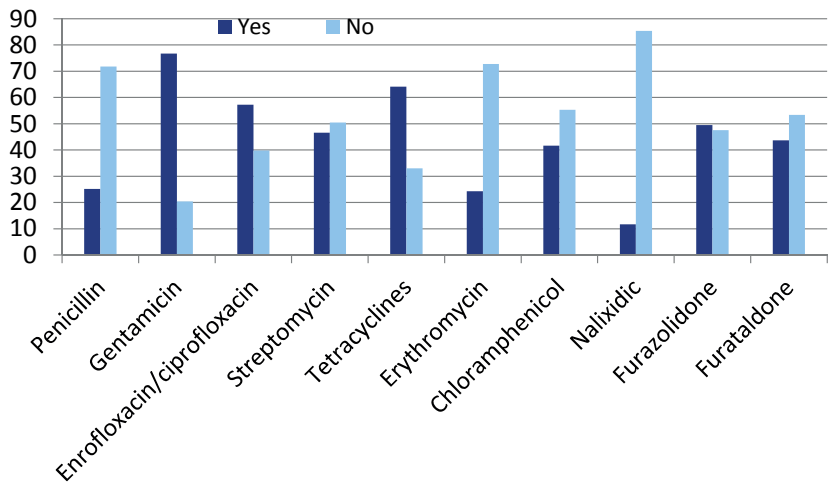

Figure 1: Antibiotics used by laying-hen farmers in Ogun State, Nigeria.

Table I

Types of antibiotics and frequency of their use in laying-hen farms in Ogun State, Nigeria

\begin{tabular}{lccc} 
Antibiotic type & \multicolumn{3}{c}{ Number of farms (\%) } \\
\cline { 2 - 4 } & Always & Occasionally & Never \\
\hline Penicillin & $8(7.8)$ & $21(20.4)$ & $74(71.8)$ \\
Gentamicin & $16(15.5)$ & $61(59.2)$ & $26(25.2)$ \\
Enrofloxacin/ & & & \\
ciprofloxacin & $15(14.6)$ & $47(45.6)$ & $41(39.8)$ \\
Streptomycin & $11(10.7)$ & $40(38.8)$ & $52(50.5)$ \\
Tetracyclines & $21(20.4)$ & $48(46.6)$ & $34(33.0)$ \\
Erythromycin & $12(11.7)$ & $15(14.6)$ & $76(73.8)$ \\
Chloramphenicol & $9(8.7)$ & $35(34.0)$ & $59(57.3)$ \\
Nalixidic acid & $8(7.8)$ & $7(6.8)$ & $88(85.4)$ \\
Furazolidone & $7(6.8)$ & $39(37.9)$ & $57(55.3)$ \\
Furataldone & $10(9.7)$ & $33(32.0)$ & $60(58.3)$
\end{tabular}

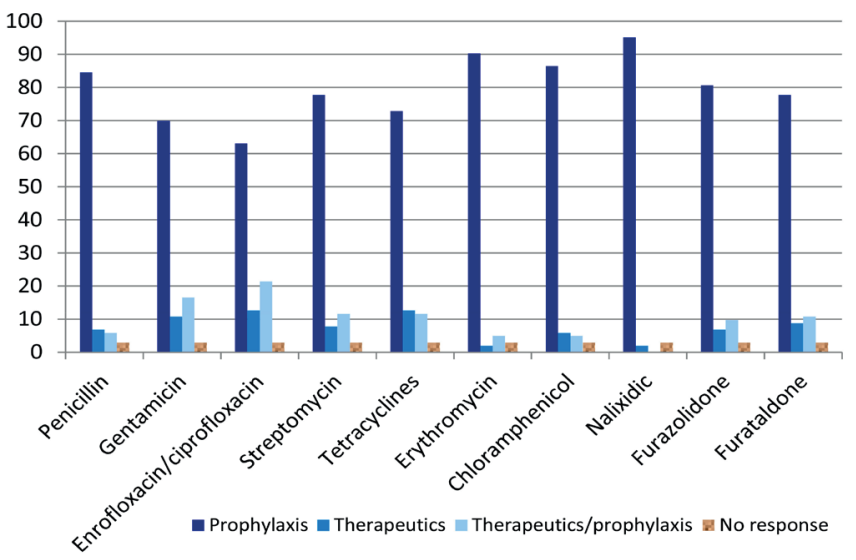

Figure 2: Farmers' objectives when using antibiotics in laying hens in Ogun State, Nigeria.
Moreover, 72 (69.9\%, 95\% CI, 60.4-77.9) disagreed with the use of higher doses of antibiotics to enhance effectiveness. Nearly $50 \%$ agreed that antibiotics used in humans could be applied in poultry disease treatment.

\section{Awareness of associated problems}

Concerning associated problems encountered with misuse of antibiotics, $82(79.6 \%, 95 \%$ CI, 70.7-86.3) farmers were aware that improper diagnosis of the disease can lead to antibiotic resistance. Likewise, $70(68.0 \%, 95 \%$ CI, 58.4-76.2) knew that antibiotic resistance is the ability of bacteria to resist the effect of antibiotics. On the other hand $73(70.9 \%, 95 \% \mathrm{CI}, 61.6-78.8)$ were not aware that misuse of antibiotics in animals poses a serious risk to human health. Data also showed that farmers felt that the public could consume eggs from hens receiving antibiotic treatment and that it would be a major loss for them if they were asked to dispose of such eggs. We observed that $72(69.9 \%, 95 \%$ CI 60.4-77.9) of the farmers lacked awareness of antibiotic residue. Many farmers 69 (67.0\%, 95\% CI, 59.4-75.3) however acknowledged that there may be associated environmental problems with improper disposal of antibiotics.

\section{Source of information on antibiotic use}

Figure 3 shows the different sources of information available to farmers on antibiotic use, and issues associated with misuse, for instance antibiotic resistance in the poultry industry. Figure 4 identifies the three main sources used by the farmers, i.e. seminars/workshops for 75 of them $(72.8 \%)$, veterinary officers for 72 (69.9\%), and other farmers for $66(64.1 \%)$.

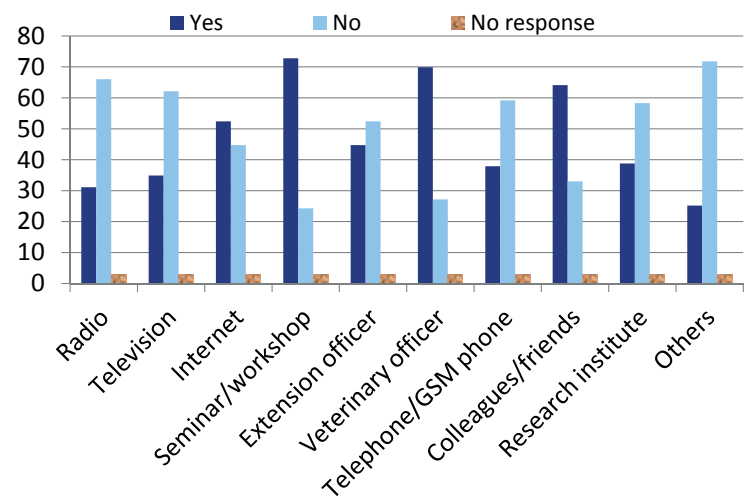

Figure 3: Sources of information on antibiotic use in laying hens available to farmers in Ogun State, Nigeria.

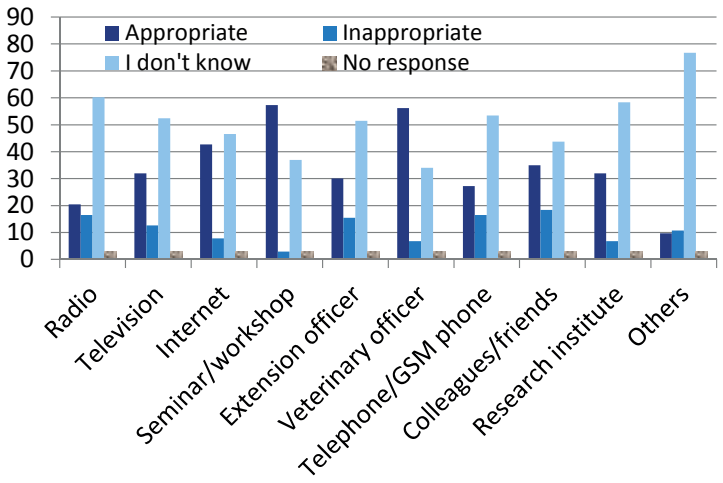

Figure 4: Farmers' preferred information sources for antibiotic awareness and use in laying hens in Ogun State, Nigeria. 


\section{DISCUSSION AND CONCLUSION}

Antibiotic usage in farm animals has raised many concerns among which the potential transfer of antibiotic resistant pathogens from animals to humans. This transfer has severe health implications including treatment failures, which has led to some deaths and increased the cost of human therapies (Lutful Kabir, 2010). Furthermore, overuse of antibiotics leads to the occurrence of harmful residues in edible poultry tissues (meat and eggs) and other animal products (Olatoye and Ehinmowo, 2009; Shareef et al., 2009; Lawal et al., 2015), which consequently are detrimental to health when such products are consumed by the public.

The most commonly used antibiotics observed in the present study were gentamicin, tetracyclines, enrofloxacin, and ciprofloxacin. This data agrees with that of Ogunleye et al. (2008), who reported enrofloxacin, tetracyclines, gentamicin, streptomycin and furaltadone as common antibiotics used among poultry farms in Ogun State. Multidrug resistance to the listed antibiotics has been reported in poultry farms in Nigeria, and the studies have attributed this to the uncontrolled use of antibiotics among farmers because of a lack of antibiotic control policies in the country (Livermore, 2003; Lutful Kabir, 2010). The use of quinolones in poultry is worrisome as this drug is classified by the World Health Organization as critically important for treatments of enteric diseases in humans and has been associated with increased resistance in humans exposed to it from farm animals. The increased use of this drug has been attributed to several factors that include its broad-spectrum activity, its easy application in water and food, and its lack of restrictions (www.soilassociation.org).

In countries such as Australia where this antibiotic is not used in food animals, cases of resistance to quinolones in farm animals have not been reported. Cases of antibiotic resistance in humans in Australia have been reported to be less than 4\% (Cheng et al., 2012). Quinolones are locally manufactured by Nigerian pharmaceutical companies and distributed to other African countries. However, some of these companies serve as major distributors of antibiotic for international manufacturers. The use of banned animal drugs including furazolidone and chloramphenicol was still well in practice among poultry farmers in the study area. Furazolidone is mostly used by farmers in the treatment of salmonellosis as the drug is commonly called a 'wonder drug'. Furazolidone and chloramphenicol in food-producing animals are banned in the United States, United Kingdom and European Union because of their carcinogenicity, mutagenicity and linkages with the development of aplastic anemia in humans (Berendsen et al., 2010; Kabir et al., 2004). Farm owners also administered antibiotics without veterinary consultation mainly because of the cost of veterinary services. A study conducted in Nigeria by Geidam et al. (2012) reported that over $80 \%$ farmers admitted having purchased antibiotics without veterinarian prescriptions, and $60 \%$ did not complete drug treatment or followed manufacturer's instructions. Antibiotics are supposed to be a restricted medicine, only handled and used by trained professionals. However, over the counter antibiotics are available from pet and human pharmacy stores for farmers' use as there are no stringent government regulations guiding prescriptions for humans and animals in Nigeria.

Results also showed that antibiotics were administered prophylactically. Most antibiotics used in poultry production in the country are administered prophylactically in drinking water or incorporated in feed (Lawal et al., 2015), as it is the case in Vietnam (Carrique-Mas et al., 2015) and in Uganda (Bashahun and Odoch, 2015). In Nigeria Ogunleye et al. (2008) reported that seven of the eight farms studied used between three and seven different antimicrobial agents at different times for prophylaxis or treatment purposes. Several reasons may have contributed to the high prophylactic usage of antibiotics in the study area. For instance, poultry were more vulnerable to salmonellosis, collibacillosis, fowl cholera, infectious bronchitis, coccidiosis, and Newcastle and Gumboro diseases, which may cause high mortality or morbidity, and huge economic losses (Kabir et al., 2004). To prevent or reduce the impact of these diseases poultry farmers tend to abuse indiscriminately antibiotics. Additionally, the predisposition to rely on personal experience sometimes leads farmers to use these drugs indiscriminately, and makes them unaware of the need to consult veterinarians, whom they all see when all obtainable means of treatment have been tried with no effect. Furthermore, the lack of hygiene and sanitary measures, the inadequacies in management and animal husbandry, and biosecurity practices may also contribute to the high use of antibiotics to prevent disease outbreaks. These shortcomings predispose birds to stress, susceptibility to infections and high pathogen transmission dynamics. To curb the extensive use of antibiotics in sub-therapeutic doses, probiotics in animal feeds and drinks have been encouraged. Probiotics are safe, and reduce intestinal infections and resistance to antibiotics (Lutful Kabir, 2010).

Farmers' main preferred source of information on antibiotic use was through seminars. The choice may have resulted from the fact that the poultry farmers' association in Ogun State holds regular meetings which encourage group talks on issues concerning the poultry industry or various challenges. We thus suggest this could be an appropriate medium with the support of government veterinarians to reduce antibiotic misuse in food animals in Nigeria. In addition, farmers agreed on the need for a policy regulating antibiotics prescription and administration by veterinarians. Along with seminars, veterinary extension services were found to be most useful for information dissemination on antibiotic use. This study serves as the basis for the development and enforcement of policies on antibiotics and banned drug use in food animals with a view to safeguard public health. An awareness campaign toward enlightening stakeholders on this topic, especially through farmers' preferred sources of information or communication is also recommended.

\section{Acknowledgments}

The authors acknowledge the Department of Veterinary Public Health, COLVET, FUNNAB, and Ogun State Ministry of Agriculture, Veterinary Services Department, for their support during this study.

\section{REFERENCES}

Adebayo O.O., Adeola R.G., 2005. Socioeconomic factors affecting poultry farmers in local area of Osun State. J. Hum. Ecol., 18 (1): 39-41

Adejoro S.O., 2007. Nigeria to worry about antibiotic resistance. World Poult., 23 (10): 10-11

Anderson A.D., Nelson J.M., Rossiter S., Angulo F.J., 2003. Public health consequences of use of antimicrobial agents in food animals in the United States. Microb. Drug Resist., 9 (4): 373-379, doi:10.1089/107662903322762815

Bashahun D., Odoch T., 2015. Assessment of antibiotic usage in intensive poultry farms in Wakiso District, Uganda. Livest. Res. Rural Develop., 27 (12), lrrd.org/lrrd27/12/bash27247.html

Berendsen B., Stolker L., De Jong J., Nielsen M., Tserendorj J.E., Sodnomdarjaa R., Elliot T.C., 2010. Evidence of natural occurrence of the banned antibiotic chloramphenicol in herbs and grass. Anal. Bioanal. Chem., 397 (5): 1955-1963, doi:10.1007/s00216-010-3724-6

Carrique-Mas J.J., Trung N.V., Hoa N.T., Mai H.H., Thanh T.H., Campbell J.I., Wagenaar J.A., Hardon A., Hieu T.Q., Schultsz C., 2015. Antimicrobial usage in chicken production in the Mekong Delta of Vietnam. Zoonoses Public Health, 62: 70-78, doi:10.1111/zph.12165

Cheng A.C., Turnidge J., Collignon P., Looke D., Barton M., Gottlieb T., 2012. Control of fluoroquinolone resistance through successful regulation, Australia. Emerg. Infect. Dis., 18 (9), 1453-1460, doi: 10.3201/ eid1809.111515

FAO, 2010. The State of Food and Agriculture. FAO, Rome, Italy 
Geidam Y.A., Ibrahim U.I., Grema H.A., Sanda K.A., Suleiman A., Mohzo D.L., 2012. Patterns of antibiotic sales by drug stores and usage in poultry farms: A questionnaire-based survey in Maiduguri, Northeastern Nigeria. J. Anim. Vet. Adv., 11: 2852-2855, doi: 10.3923/javaa.2012.2852.2855

Ghosh S., Lapara T.M., 2007. The effects of subtherapeutic antibiotic use in farm animals on the proliferation and persistence of antibiotic resistance among soil bacteria. ISME J., 1 (3): 191-203, doi:10.1038/ismej.2007.31

Gustafson R.H., Bowen R.E., 1997. Antibiotic use in animal agriculture. J. Appl. Microbiol., 83 (5): 531-541, doi: 10.1046/j.13652672.1997.00280.x

Hurd H.S., Doores S., Hayes D., Mathew A., Maurer R J., Silley P., Jones R.N., 2004. Public health consequences of macrolide use in food animals: a deterministic risk assessment. J. Food Protect., 67 (5), 980-992

Kabir J., Umoh V.J., Audu-Okoh E., Umoh J.U., Kwaga J.K.P., 2004. Veterinary drug use in poultry farms and determination of antimicrobial drug residues in commercial eggs and slaughtered chicken in Kaduna State, Nigeria. Food Contam., 15 (2), 99-105, doi:10.1016/S0956-7135 (03)00020-3

Lawal J.R., Saleh M.J., Yaqub A.G., Amina M.B., Yakaka W., Muhammad M., 2015. Antibiotic residues in edible poultry tissues and products in Nigeria: A potential public health hazard. Int. J. Anim. Vet. Adv., 7 (3): 55-61
Livermore D.M., 2003. Bacterial resistance: origins, epidemiology, and impact. Clin. Infect. Dis., 36: S11-S23, doi:10.1086/344654

Lutful Kabir S.M., 2010. Avian colibacillosis and salmonellosis: A closer look at epidemiology, pathogenesis, diagnosis, control and public health concerns. Int. J. Environ. Res. Public Health, 7 (1): 89-114, doi:10.3390/ ijerph7010089

Nunnally J.C., Bernstein I.H., 1994. Psychometric theory, 3rd ed. McGrawHill, New York, USA, 736 p.

Ogunleye A.O., Oyekunle M.A., Sonibare A.O., 2008. Multidrug resistant Escherichia coli isolates of poultry origin in Abeokuta, South Western Nigeria. Vet. Arh., 78 (6): 501-509

Olatoye I.O., Ehinmowo A.A., 2009. Oxytetracycline residue in edible tissue of cattle slaughtered in Akure, Nigeria. Internet J. Food Saf., 11: 62-66

Olonitola O.S., Fahrenfeld N., Pruden A., 2015. Antibiotic resistance profiles among mesophilic aerobic bacteria in Nigerian chicken litter and associated antibiotic resistance genes. Poult. Sci. , 94 (5): 867-874, doi:10.3382/ps/pev069

Shareef A.M., Jamel Z.T., Yonis K.M., 2009. Detection of antibiotic residue in stored poultry products. Iraq J. Vet. Sci., 23 (1): 45-48

\section{Resumen}

Adebowale O.O., Adeyemo O.K., Awoyomi O., Dada R., Adebowale $\mathbf{O}$. Uso y prácticas de antibióticos en gallinas ponedoras comerciales en el estado de Ogun Nigeria

bowale $\mathrm{O}$. Pratiques d'utilisation des antibiotiques dans les élevages de poules pondeuses dans l'Etat d'Ogun au Nigeria

La production de volailles occupe une place prépondérante dans l'économie nigériane. Toutefois, I'utilisation abusive des antibiotiques par les éleveurs de volailles a entraîné une multirésistance et nuit à l'efficacité des traitements antibiotiques dans l'industrie. Cette étude a été réalisée afin d'évaluer l'utilisation d'antibiotiques dans les exploitations avicoles commerciales. Une enquête a été menée à l'aide d'un questionnaire structuré destiné aux chefs d'exploitation pour obtenir des informations sur les caractéristiques socio-économiques des propriétaires ou desdits chefs, les types d'antibiotiques utilisés, la fréquence et la raison de leur utilisation, la sensibilisation à l'usage des antibiotiques et à leurs problèmes associés, et les sources d'information privilégiées par les éleveurs pour un recours raisonnable aux antibiotiques. Le niveau d'instruction des interviewés était universitaire ou équivalent $(70,9 \%)$, collège ou lycée $(12,6 \%)$, ou sans éducation formelle (13,6\%). Les antibiotiques étaient utilisés principalement en prophylaxie (> $60 \%$ ) et en thérapeutique $(<15 \%)$. La gentamicine $(76,7 \%)$ était l'antibiotique le plus utilisé, venaient ensuite la tétracycline $(64,1 \%)$, I'enrofloxacine et la ciprofloxacine $(57,3 \%)$, la furazolidone $(49,5 \%)$, la streptomycine $(46,6 \%)$, la furaltadone $(43,7 \%)$, le chloramphénicol $(41,7 \%)$, la pénicilline $(25,2 \%)$, l'érythromycine $(24,3 \%)$, et I'acide nalidixique (11,7\%). Environ la moitié des exploitations agricoles utilisaient les produits interdits que sont la furazolidone et le chloramphénicol. Au total 82 (79,6\%) éleveurs savaient que I'utilisation aléatoire d'antibiotiques dans le traitement de maladies incorrectement diagnostiquées pouvait conduire à la résistance aux antibiotiques. Cependant, 73 (70,9\%) étaient moins informés sur le fait qu'un mauvais usage des antibiotiques chez les animaux constitue une grave menace en santé humaine. Les antibiotiques n'étaient pas utilisés avec prudence par les producteurs de volailles. Le manque de sensibilisation de ces derniers à cette situation serait un facteur qui y contribuerait. Les résultats de cette enquête devraient permettre d'élaborer des politiques pertinentes pour établir un contrôle de l'utilisation des antibiotiques dans les élevages de volailles au Nigeria.

Mots-clés : volaille, poule pondeuse, résistance aux antibiotiques, résidus d'antibiotiques, chef d'exploitation, Nigeria
La producción avícola contribuye en gran medida a la economía nigeriana. Sin embargo, el mal uso de antibióticos por parte de los avicultores ha llevado a la resistencia a múltiples drogas e impide la eficacia de los tratamientos con antibióticos en la industria. Este estudio se realizó con el fin de evaluar el uso de antibióticos en las granjas avícolas comerciales. Se llevó a cabo una encuesta mediante un cuestionario estructurado granja-administrador para obtener información sobre las características socioeconómicas de los dueños/administradores de la granja, los tipos de antibióticos utilizados, su frecuencia y el propósito de su uso, el conocimiento del uso de antibióticos y las consecuencias asociadas, y las preferencias de los agricultores en cuanto a los canales de difusión de la información sobre el uso adecuado de antibióticos. El nivel de educación de los encuestados fue la universidad $(70,9 \%)$, la escuela secundaria $(12,6 \%)$ o sin educación formal $(13,6 \%)$. Los antibióticos se utilizan principalmente para la profilaxis (> 60\%) y terapéutica $(<15 \%)$. Gentamicina $(76,7 \%)$ fue el más utilizado, seguido por tetraciclina $(64,1 \%)$, enrofloxacino y ciprofloxacina $(57,3 \%)$, furazolidona $(49,5 \%)$, estreptomicina $(46,6 \%)$, furaltadona $(43,7 \%)$, cloranfenicol $(41,7 \%)$, penicilina $(25,2 \%)$, eritromicina $(24,3 \%)$ y ácido nalidíxico $(11,7 \%)$. Aproximadamente la mitad de las granjas utilizaron furazolidona prohibida y el cloranfenicol. En total $82(79,6 \%)$ agricultores estaban conscientes de que el uso de antibióticos al azar para el tratamiento de enfermedades incorrectamente diagnosticadas puede conducir a la resistencia a los antibióticos. Sin embargo, $73(70,9 \%)$ estaban menos conscientes de que el mal uso de antibióticos en animales representa una seria amenaza para la salud humana. Los antibióticos no fueron utilizados con prudencia por los productores de aves de corral, y la falta de conciencia sobre esta cuestión podría ser un factor contribuyente. Se prevé que el resultado de esta encuesta ayudará en el desarrollo de políticas pertinentes para el control en el uso de antibióticos en las granjas avícolas en Nigeria.

Palabras clave: ave de corral, gallina ponedora, resistencia a los antibióticos, residuos de antibióticos, gestor de empresas agrarias, Nigeria 
